\title{
Borç Krizi Ekseninde Avrupa'da Sigorta Prim Üretiminin Gelire Dayalı Belirleyicileri
}

\author{
In the Debt Crisis Axis Income-based Determinants of Insurance Premium \\ Production In Europe
}

\author{
K. Batu TUNAY', \\ Necla TUNAY2
}

0000-0002-9040-5831

0000-0002-8765-276X

\begin{abstract}
ÖZET
Bu çalışmada Avrupa ülkeleri örneğinden hareketle gelişmiş ve yükselen ülkelerde sigorta şirketlerinin prim üretimlerinin gelire dayalı belirleyicileri araştırılmıştır. Ayrıca küresel kriz ve takiben Avrupa'da yaşanan borç krizi çerçevesinde; refah düzeyinin ve sigorta bilincinin yüksek olduğu ülkelerde sigorta şirketlerinin prim üretimlerinin krizlerden nasıl etkilendiği de incelenmiştir. Analizler dinamik panel veri modelleriyle ve 32 ülkenin verileri kullanılarak yapılmıştır. Ulaşılan bulgular sigorta şirketlerinin prim üretimlerinin kişi başına satın alma gücü ve kişi başına tasarruf gibi gelir temelli belirleyicilerden etkilendiğini göstermektedir. Çıktı açığı ve işsizlik gibi ekonominin faaliyet düzeyini gösteren değişkenler de prim üretimi üzerinde etkilidir. Ayrıca ardı ardına meydana gelen ciddi krizlerin de sigorta prim üretimini düşürdüğü belirlenmiştir.
\end{abstract}

Anahtar Kelimeler: Sigorta, prim üretimi, finansal krizler, sistem dinamik panel veri

\section{GiRiş}

Avrupa sanayileşme ve refah düzeyi açılarından gelişmiş ülkeleri barındırmaktadır. Gelişmişlik düzeyi nispeten düşük Avrupa ülkeleri bile yükselen ekonomiler arasında üst sıralarda gösterilmektedir. Avrupa ülkeleri arasındaki ekonomik gelişmişlik farkları fazla derin olmasa da, özellikle Avrupa Birliği süreci üye ülkeler arası makro ekonomik dengesizlikleri körüklemiş ve içten içe kamu maliyesi odaklı kırılganlıkların artmasına neden olmuştur. Son otuz yıllık süreçte gelişmekte olan Avrupa ülkelerinin artan büyüme hızlarına paralel olarak toplam talepleri de artmıştır.

\begin{abstract}
In this study, it is analyzed the income based determinants of premiums that produced by insurance companies in developed and emerging economies from the European case. Within the framework of the debt crisis in Europe, it has also been investigated how premium production of insurance companies is affected by crises in countries where wealth and insurance awareness are high. The analyzes were performed using system dynamic panel data models and data from 32 countries. Findings indicate that premium production of insurance companies is affected by income-based determinants such as per capita purchasing power and per capita savings. The variables such as output gap and unemployment that indicating volume of the economic activity have also an impact on the insurance premiums. In addition, it was determined that the serious crises that took place behind one after another also reduced premium production.
\end{abstract}

Keywords: Insurance, premium production, financial crisis, system dynamic panel data 
büyük bir krize dönüşmesine neden olmuştur. 2007 öncesinde Avrupa merkezli büyük finansal aracıların $A B D$ finans piyasalarındaki spekülatif işlemlere dahil oldukları görülmüştür. Başta konut piyasası olmak üzere $A B D$ finansal piyasalarındaki çok karlı ama riskli yatırım fırsatlarından payına düşeni almak isteyen ve portföylerinde bu riskli varlıklara fazlasıyla yer veren Avrupalı finansal aracılar, krizin akabinde ciddi bir mali çöküşün eşiğine gelmiştir. Sistemik riski yüksek bu kuruluşların batmasının neden olabileceği maliyetler karşısında onları iflastan kurtarmaktan başka seçenekleri olmayan Avrupa devletlerinin kamu maliyesi dengeleri yara almıştır. Bir süre sonra krizin etkileri çeşitli kanallarla Avrupa'nın nispeten zayıf ekonomilerine de sıçramış ve yaygın bir borç krizinin doğmasına neden olmuştur. Finansal krizin borç krizine dönüşmesi sürecinde karşılıklı yüksek ekonomik bağlılıklar, ortak para sistemi ve bankacılık sistemi temel mekanizmaları oluşturmaktadır. Avrupa borç krizinin iki boyutu vardır. Illki kamu maliyesi hassas ve nispi gelişmişliği düşük Avrupa ülkelerinin borçlarını ödeme güçlüğüne düşmesidir. İkinci boyut ise; küresel finansal krizden etkilenen finansal sistemlerini toparlama gayretindeki gelişmiş Avrupa ülkelerinin, finanse ettikleri komşularından alacaklarını tahsilde yaşadıkları güçlüklerdir.

Böyle bir ortamda Avrupa ülkelerinin diğer finansal piyasaları yanında sigorta piyasası da ciddi sorunlar yaşamıştır. Sigorta şirketlerinin finansal krizlere duyarlılığı yatırım portföylerindeki varlıkların piyasa riski düzeyine bağlı olarak değişmektedir. Bununla beraber 2000'lerin başlarından itibaren sigorta şirketlerinin banka kredilerine teminat verdikleri yeni bir sürecin başladığı da gözlenmiştir. Avrupa'da çok güçlü olmasa bile, bu yeni sürecin de sigorta şirketlerinin kriz karşısındaki kırılganlıklarını arttırdığı söylenebilir (Baghus, 2011: 138, Tamura ve Tabakis, 2013: 24). Bankalarla ve diğer finansal aracılarla güçlü karşılıklı bağlar nedeniyle, borç krizi deneyimi Avrupa sigorta sektörü için sistemik risk ve risklerin bulaşıcılığı olasılıklarını arttırmış ve bu konularda ciddi önlemler alınması zorunluluğunu doğurmuştur (IMF, 2016; ESRB, 2015). Uzmanlar borç krizi nedeniyle doğan kamu finansman sorunlarının, sigorta şirketlerinin yatırım portföylerinde bulundurdukları kamu borçlanma kağıtlarını riskli hale getirdiğini ifade etmektedir (Düll vd., 2015; Reinhart ve Rogoff, 2013; Wilson, 2013). Özellikle hayat sigortası şirketleri ve emeklilik fonlarının büyük yatırım portföylerinde kamu kağıtlarının payı oldukça yüksektir. Dolayısıyla bu gibi kuruluşların borç krizi nedeniyle maruz kaldıkları riskler artmıştır (Wilson, 2013, Impavido ve Tower, 2009).

Bu değerlendirmeler ışığında sigorta şirketlerinin operasyonel anlamda krizin etkilerine maruz kaldıkları gözlenmektedir. Ancak bu şirketlerin kaynak yapılarının krizden ne şekilde etkilendiği konusu pek açık değildir. Krizin yaygınlaşmasıyla birçok Avrupa ülkesinde ekonomik faaliyet hacmi daralmış, işsizlik oranları yükselmiş, insanların satın alma güçleri düşmüştür. Bu koşullar altında sigorta ürün ve hizmetlerine olan talebin daralması beklenebilir. Diğer yandan gelir düzeyi yüksek, refahın tabana yayıldığı ve yerleşik bir sigorta bilinci olan Avrupa'da sigorta talebinin çok fazla azalmayacağı da ileri sürülebilir. İdeal bir sigorta piyasası olan Avrupa'da sigorta şirketlerinin prim üretimlerinin böyle şiddetli bir krizden ne şekilde etkilendikleri belirlenebilirse, gelecekte benzer krizler karşısında sigorta şirketlerinin kaynak yapılarının nasıl bir değişim göstereceği ve ne gibi önlemler alınması gerektiği de öngörülebilecektir.

Büyük krizler sonucunda ekonomik faaliyet hacmi daralan ülkelerde, işsizliğin artması kişi başına gelir düzeyini düşürmektedir. Diğer yandan kriz ve takip eden durgunluk dönemlerinde işsiz kalmak istemeyen birçok kişinin daha düşük ücretlerle çalışmaya razı oldukları da geçmiş kriz deneyimlerinden bilinmektedir. Gerek işsizlik, gerekse istihdam edilenlerin gelir düzeylerindeki daralmalar fiyatlar genel düzeyi sabit kaldığında, hatta kısmen düştüğünde bile insanların satın alma güçlerinin zayıflamasına neden olabilmektedir. Ama emek piyasalarının son derece etkin çalıştığı, güçlü bir sendikal yapı ve işsizlik sigortası gibi düzenlemelerin olduğu Avrupa ülkelerinde ücretlerin büyük düşüşler göstermesi zor göründüğünden, yukarıdaki tespitlerin geçerliliği sorgulanabilir. Ayrıca kişi başına gelir düzeyi oldukça yüksek olan Avrupa ülkelerinde, yerleşik bir sigorta bilinci ve yüksek sigorta talebi olması nedeniyle prim üretimi ile kişi başına gelir ve kişi başına satın alma gücü arasında uzun dönemli güçlü ilişkiler olup olmadığı da tartışmaya açıktır. Bu gibi tartışmalı hususlar oldukça fazladır ve kuşkusuz tek bir deneysel çalışma ile aydınlatılmaları olası değildir.

Bu tespitler ışığında çalışmamız Avrupa örneği üzerinden gelişmiş ve refah düzeyi yüksek ülkelerde prim üretiminin başlıca belirleyicilerini ortaya koymayı hedeflemektedir. Buna ek olarak, küresel kriz ve borç krizi gibi iki önemli kırılmanın primler üzerindeki etkileri de araştırılacaktır. Ulaşılan bulguların tartışmaIı konulara tam bir açıklık getiremese bile bazı önemli 
tespitler yapılmasına imkan vermesi beklenmektedir. Çalışmada $A B$ üyesi olan ve olmayan 32 Avrupa ülkesinden derlenen bir veri seti kullanılarak sistem dinamik panel veri modelleriyle prim üretiminin belirleyicileri araştırılmaktadır. Yapılan modellemede gelir düzeyi, satın alma gücü, tasarruf düzeyi gibi değişkenler yanında, hem küresel krizin hem de Avrupa borç krizinin etkilerinin belirlenebilmesi için gölge değişkenler eklenmiştir. Çalışmanın ilgili literatüre başlıca katkıları, analizlerin benzer deneysel çalışmalara oranla daha kapsamlı bir örnekleme dayanması, bu alanda nispeten az kullanılmış bir analiz yöntemi uygulanması ve tahmin edilen modellerde krizlerin etkilerinin doğrudan dikkate alınmış olması şeklinde sıralanabilir.

Çalışma giriş ve sonuç haricinde iki ana bölümden oluşmaktadır. Bu bölümlerden ilki sigorta talebi ve prim üretiminin belirleyicileri konusunda yapılmış deneysel çalışmaları ve bunların başlıca bulgularını içeren bir literatür taramasıdır. İkinci ana bölümdeyse, analizde kullanılan modelin yapısı, analiz yöntemi, veri seti ve tahmin bulgularını içeren ekonometrik analizlere yönelik açıklamalar yer almaktadır.

\section{LITTERATÜR TARAMASI}

Sigorta şirketlerinin prim üretimlerinin belirleyicilerini ele alan çalışmaların sayısı oldukça azdır. Buna karşılık literatürde, sigorta ürünlerine olan talebi ele alan oldukça fazla çalışmaya rastlanmaktadır. Talep konusunda yapılan çalışmaların çoğunluğu hayat sigortaları alanındadır. Hammond vd. (1967), Gius (1998), Benson ve Marks (2011), Moldogaziev ve Johnson (2011), Willie (2015) prim üretimi konusundaki belli başlı çalışmalardır. Sıralanan bu çalışmalardan Hammond vd. (1967), Willie (2015) dışındakiler analiz ettikleri konu itibariyle sigorta prim üretiminin gelirle ilgili belirleyicilerini dikkate almazlar. ${ }^{1}$ Hammond vd. (1967), hayat sigortası prim harcamalarının gelir esnekliğini doğrusal olarak modellemişlerdir. Hane halkının ortalama yaşam süresi, eğitim durumları ve icra ettikleri meslek gibi değişkenlerin prim harcamaları üzerinde etkili olduğunu belirlemişlerdir. Willie (2015) ise; Güney Afrika'da özel sağlık sigortası yaptıranların ödedikleri primi analiz etmiştir. Ortalama yaş, tazminat ödemeleri ve yapılan sağlık sigortası prim ödemeleri arasında belirli bir ilişki olduğu gözlenmiştir. Piyasaya hâkim sigorta şirketlerinin uyguladıkları prim politikalarıyla küçük ölçekli rakiplerini saf dışı bıraktığı belirlenmiştir. Daha açık bir deyişle, prim oranları üzerinden bir fiyat rekabeti sürdürülmekte ve bu da prim tahsilatlarını doğrudan etkilemektedir. Willie'nin bulguları prim üretiminin gelir yanında sektördeki rekabetten de etkilendiğini göstermesi bakımından önemlidir.

Sigorta talebinin belirleyicileri konusundaki başlıca çalışmalar; Beck ve Webb (2002), Hwang ve Gao (2003), Hussels vd. (2005), Enroljes ve Sentis (2008), Gius (2010), lbiwoye vd. (2010), Lee vd. (2010), lbok (2012), Kjosevski (2012), Curak v.d. (2013), Jakovcevic ve Zaja (2014), Guierneau ve Sawadago (2015), Luciano vd. (2015), Sarkodie ve Yusif (2015), Alhassan ve Biekpe (2016) olarak sıralanabilir. Enroljas ve Sentis'in (2008) Fransa'da tarım sigortası talebi, Hussels vd. (2005) sigorta talebinin belirleyicilerinden hareketle sigorta piyasalarını geliştirecek faktörlere, Ibok (2012) sağlık sigortası talebine yönelik analizleri dışındaki hemen tüm çalışmalar hayat sigortası ürünlerine olan talebi ve bunun belirleyicilerini ele almaktadır. Söz konusu çalışmalarda, sigorta ürünlerinin talebi gelir kadar demografik ve sosyo-kültürel değişkenlerle de açıklanmaktadır. Ibiwoye vd. (2010), Guierneau ve Sawadago (2015), Sarkodie ve Yusif (2015) gibi araştırmacılar çeşitli Afrika ülkelerindeki hayat sigortasının sosyo-kültürel ve ekonomik belirleyicilerini analiz etmektedir. Diğer çalışmalar geliş̧miş ve yükselen ekonomilerdeki sigorta talebi üzerinedir.

Sigorta ürünlerine yönelik talebin başlıca göstergeleri satılan poliçe sayısı ve tahsil edilen primler veya teknik tabirle prim üretimidir. Poliçe sayısı sigorta talep miktarı hakkında önemli ölçüde fikir verse de, talep miktarını parasal olarak yansıtmadığından yanıltıcı olabilir. Bu bakımdan prim üretimi talebin parasal boyutunu belirlemek için daha uygun bir ölçüttür. Prim üretiminin temel dinamikleri benzer olsa bile, bağlantılı olduğu sigorta türüyle ilişkili dinamikler de söz konusudur. Genelde hemen tüm poliçe satışları, eğitim durumu, sigorta bilinci, gelir düzeyi ve satın alım gücü gibi değişkenlerden etkilenmektedir. Ancak hayat dışı sigorta poliçe satışı ve prim üretiminin gelire ve alım gücüne daha duyarlı olduğu, hayat ve sağlık poliç̧e satışları ve prim üretimlerinde (eğer toplumun sigorta bilinci de yüksekse) bu faktörlere duyarlılığın düşük olduğu görülür. Örneğin enflasyon artışları konut poliçelerine olan talebi ve prim üretimini düşürebilir, ama birikimli bir hayat poliçesine olan talebi düşürmeyecektir. Bununla beraber geçici de olsa tam gelir kaybına yol açan işsizlik oranlarının artması, hayat ve sağlık poliçe satışlarını, dolayısıyla prim üretimlerini düşürebilir. 
Literatürdeki çalışmaların büyük bir bölümü hayat sigortası prim üretimini temel aldığından yaş, cinsiyet, medeni durum, ortalama yaşam süresi, eğitim düzeyi, din, istihdam durumu, icra edilen meslek gibi demografik ve sosyal değişkenlerin sigorta talebini açıklamakta öne çıktığı görülmektedir. Bunların yanında kişi başına gelir düzeyi, kişi başına satın alım gücü, gelecekteki gelir beklentisi, primlerin gelir esnekliği gibi gelir temelli değişkenler önemli talep belirleyicileri arasındadır. Yükselen ekonomilerde enflasyon, ekonomik ve politik reformlar, sosyal yapıdaki değişim gibi başka faktörlerin de dikkate alındığı görülmektedir. Nüfus yapısı ve sosyo-kültürel özelliklere dair değişkenlerin sigorta talebine etkisi ülkeden ülkeye değişkenlik göstermektedir. Gelişmiş, refah ve eğitim düzeyleri yüksek ülkelerde sigorta bilinci yüksek olduğundan daha istikrarlı bir sigorta talebi söz konusudur. Ancak gelişmekte olan ülkelerde talep hem demografik, hem sosyal hem de ekonomik değişimlerden yüksek oranda etkilenmektedir².

Değinilen deneysel çalışmalar analiz yaklaşımları ve yöntemleri açısından ikiye ayrılabilir. Çalışmaların büyük bir kısmı belirli bir ülkenin sigorta sistemini ve bu sistemde faaliyet gösteren firmaların ürünlerine olan toplam talebi analiz etmektedir. Bu gibi çalışmalarda genelde çok değişkenli regresyon, lojistik regresyon veya Tobit gibi tek boyutlu modellere dayanan analizler tercih edilmiştir. Birden fazla ülkenin sigorta sistemlerini ve/veya belirli bir ülkede faaliyet gösteren sigorta şirketlerinin ürün taleplerini analiz eden çalışma sayısı azdır. Çok ülkeli veya firmalı çalışmalarda doğrusal panel veri yöntemlerine dayalı analizlerin yapıldığı görülmektedir. Beck ve Webb (2002), Kjosevski (2012), Guierneau ve Sawadago (2015) çalışmaları çok ülkeli çalışmaların başlıca örnekleridir. Belirtilen çalışmaların örneklem yapısı ve tercih edilen analiz yöntemleri için Ek Tablo 1'e bakılabilir.

Küresel finansal kriz sigorta sektörünün ödeme gücünü bankalar kadar tehdit etmemişse de, önemli olumsuz etkiler yaptığı da reddedilemez bir gerçektir. Birçok sigorta şirketi, ABD ipotek piyasası ve bağlantılı piyasaların aktiflerine sahip olduğundan krizin merkezinde yer almıştır. Genelde sigorta şirketleri krizden yatırım portföylerinde yer alan yüksek riskli varlıklar nedeniyle etkilenmiş olsalar da, azımsanamayacak şirket de hem ABD ipotek piyasasındaki hem de banka piyasalarındaki aracılara teminat vererek ciddi riskler üstlenmişlerdir. Böylece piyasa riskine ek olarak kredi riskine de maruz kalmışlardır. Sigorta şirketlerinin mali bünyeleri piyasa riskini belirli ölçüde karşılayabilse bile, kredi riskine uygun değildir. Küresel kriz sürecinde ve hemen akabinde Avrupa borç krizi esnasında bu gibi risklere giren sigorta şirketlerinin ciddi sorunlar yaşadıkları görülmüştür. AIG örneği bunların belki de en bilinenidir. Bu ve diğer birkaç önemli örnekten ötürü Impawido ve Tower (2009), Klein vd. (2009), Schich (2009, 2010), Liedtke ve Schanz (2010) Kocovic vd. (2011) gibi bazı araştırmacılar sigorta şirketlerinin krizdeki rolünü sorgulamışlardır.

Avrupa'da yaşanan borç krizi sigorta şirketlerinin prim üretimlerini ciddi oranda düşürmüştür. Yunanistan gibi bazı ülkeler haricinde, Avrupa 2012'den sonra bir ekonomik toparlanma sürecine girmişse de; sigorta şirketlerinin toplam prim üretimlerindeki düşüş eğilimi devam etmiştir. Grafik 1'de bu gelişim açık şekilde görülmektedir. Hayat sigortası şirketlerinin prim üretimleri bu gelişmelerden daha az etkilenmiştir (Bkz. Ek Tablo 4). Bununla beraber, Düll vd. (2015), Reinhart ve Rogoff (2013), Wilson (2013), Impavido ve Tower (2009) gibi bazı araştırmacıların işaret ettikleri gibi; özellikle büyük yatırım portföyleri olan hayat sigortası şirketleri ve emeklilik fonları için borç krizi risklerin ve kırılganlıkların artmasına neden olmuştur. Krizle beraber birçok Avrupa ülkesi kamu finansman açıklarını kapatmak için daha fazla borçlanma aracı yayınlamış ve sigorta şirketleri portföylerinde bunlara önemli oranda yer vermiştir. Böylece hem kamu borçlarıyla beraber sigorta portföyleri de büyümüş hem de şirketlerin maruz kaldıkları riskler yükselmiştir (Bkz. Grafik 2). Burada asıl ilginç ve önemli husus, bu borçlanma araçlarının sigorta şirketlerinin bilanço yapıları itibariyle yönetemeyecekleri faiz ve ödememe risklerine maruziyetlerini arttırmış olmasıdır. Sistemi tehdit eden asıl sorun da zaten budur. Özetle, büyüme ile prim üretimi arasında güçlü pozitif bir ilişki vardır. Buna bağlı olarak ekonomi durgunluğa girdiğinde prim üretimi de azalmaktadır. Borç krizi özelinde, net kamu borçlanması ile toplam prim üretimindeki artış arasında negatif, net kamu borçlanması ile yatırım portföylerinin büyümesi arasında pozitif güçlü ilişkiler gözlemlenmiştir (Bkz. Grafik 3). 
Grafik 1: Avrupa Birliği'nde Toplam Prim Üretimi ve Ekonomik Büyüme Ilişkisi (\% Değişim)

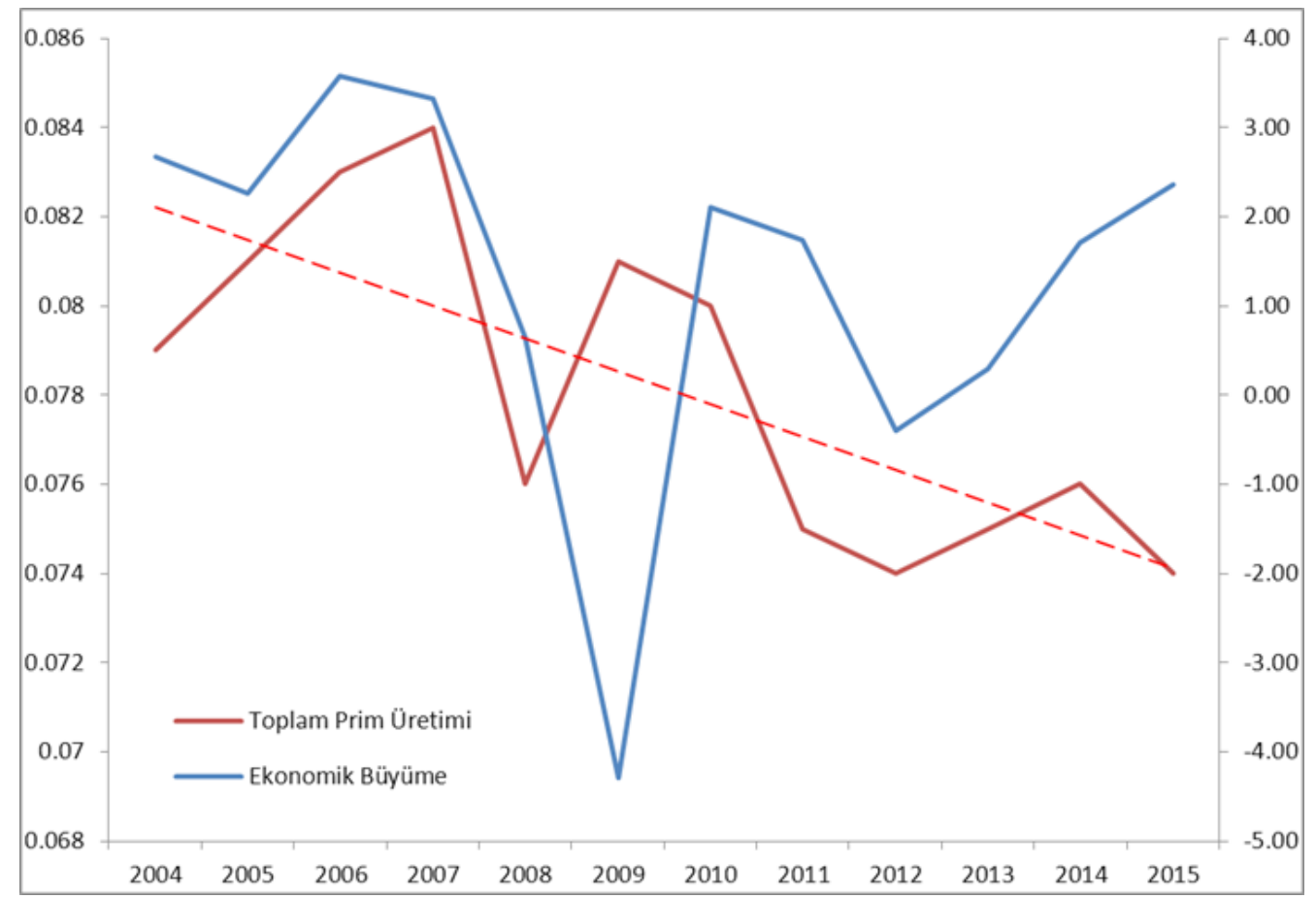

Kaynak: Insurance Europe, European Insurance Industry Database, 2017; International Monetary Fund, World Economic Outlook Database, April 2017. Ekonomik büyüme sağ eksende gösterilmiştir.

Grafik 2: Avrupa Birliği'nde Net Kamu Borçları ile Sigorta Sektörünün Yatırım Portföyü Arasındaki ilişki (\% Değişim)

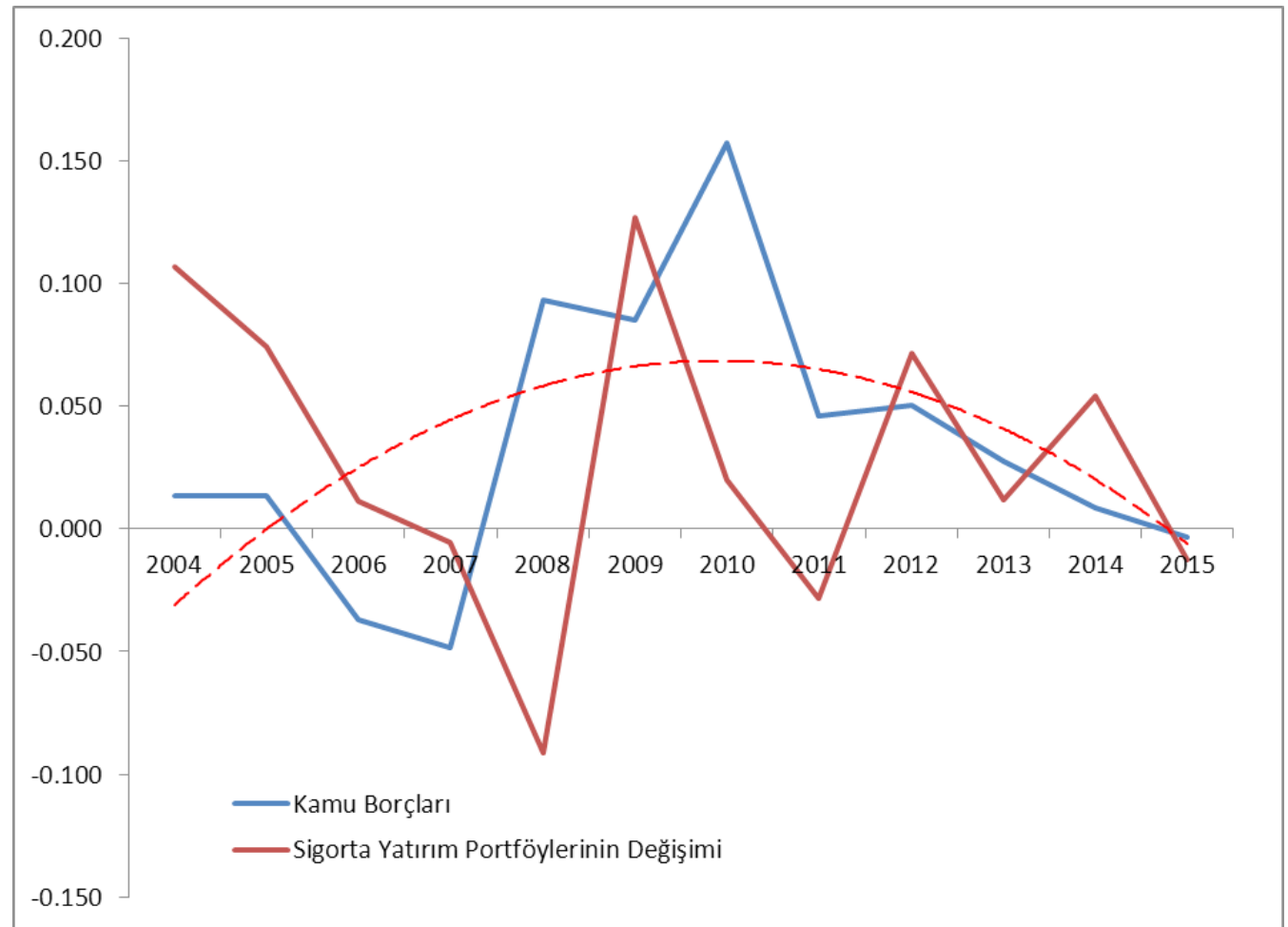

Kaynak: Insurance Europe, European Insurance Industry Database, 2017; International Monetary Fund, World Economic Outlook Database, April 2017. 

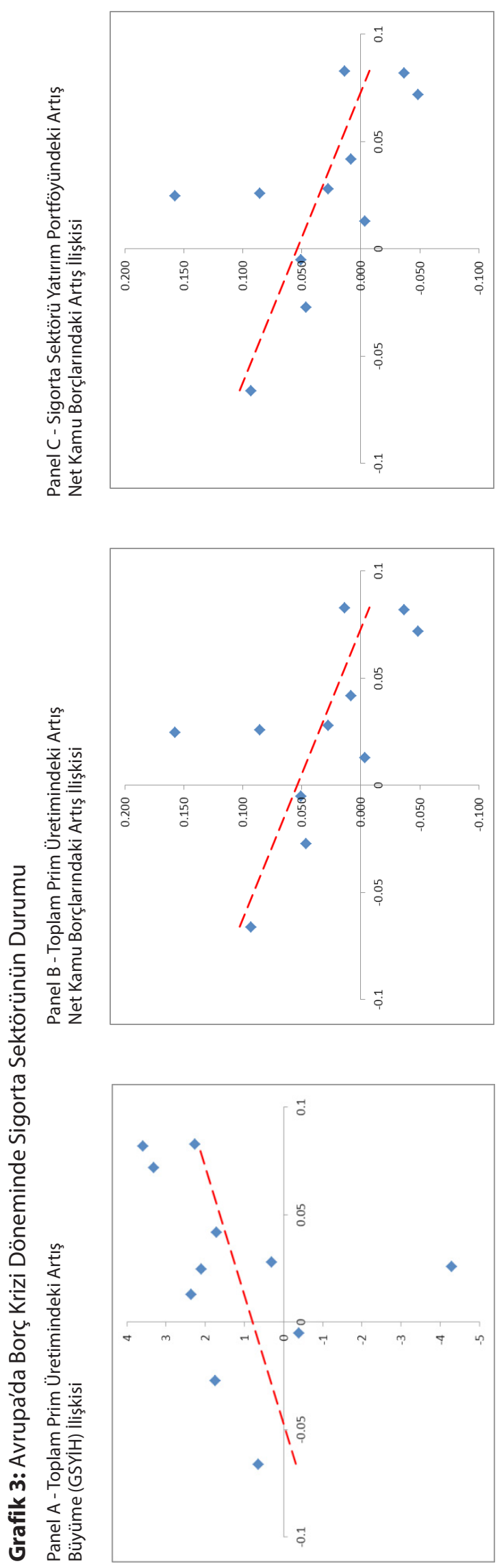

Literatürde Avrupa'daki borç krizinin sigorta şirketlerine olan etkilerine dair çalışmaların sayısı oldukça azdır. Needleman vd. (2012), Malafronte vd. (2014), Bijlsma ve Vermeulen (2015) çalışmaları bunların belli başııları olarak sıralanabilir. Bunlardan sadece son ikisi deneysel çalışmalardır ve sadece belirli etkilere odaklanmışlardır. ${ }^{3}$ Malafonte vd. (2014) 2005-2010 dönemi için 47 sigorta şirketinin verilerini doğrusal panel regresyon modelleriyle analiz etmiştir. Bijlsma ve Vermeulen (2015) ise, 2006-2013 dönemi için 60 sigorta şirketinin üçer aylık yatırım portföy verilerini kapsayan ve doğrusal panel regresyon ve sabit etkiler modellerine dayanan benzer bir analiz yapmışlardır. Her iki çalışma da sigorta şirketlerinin borç krizinden olumsuz etkilendiklerini ortaya koymuştur. Dolayısıyla Avrupa örneği üzerinden yapılacak analizlerde hem küresel krizin hem de borç krizinin etkilerinin dikkate alınması gerektiği görülmektedir.

\section{EKONOMETRIK ANALIZ VE BULGULAR}

\subsection{Modellerin Yapısı ve Analiz Yöntemi}

Uygulamalı sigorta literatüründe prim üretiminin belirleyicileri konusunu doğrudan ele alan çalışmaya rastlanmamıştır. Alternatif olarak sigorta talebinin belirleyicilerini analiz eden çalışmalar dikkati çekmektedir. Bunların da sayıları fazla değildir. Gius (2010), Lee vd. (2010), Jakovcevic ve Zaja (2014), Alhassan ve Biekpe'nin (2016) çalışmaları, sigorta talebinin belirleyicileri konusunda nispeten yeni tarihli uygulamalı araştırmalardan bazılarıdır. Belirtilen bu çalışmalarda, genellikle sigorta ürünlerinin talebi demografik ve gelir temelli değişkenlerle açıklanmaktadır. Bizim araştırmamız demografik değişkenlerin nispeten istikrarlı olduğu Avrupa ülkelerini konu aldığından ve son dönemde meydana gelen önemli krizlerin etkilerine odaklandığından demografik yapıyı tasvir eden değişkenler kasten ihmal edilmiştir. Bunun yerine gelir ve refah düzeylerini yansıtan değişkenlere ağırlık verilmiştir. Temel amacımız genel olarak refah düzeyi yüksek ve sigorta bilinci gelişmiş olan Avrupa ülkelerinde son dönemde meydana gelen önemli krizlerin ekonomik birimlerin gelirleri kanalıyla sigorta şirketlerinin prim üretimlerine etkilerini gözlemlemektir. Bu çerçevede prim üretimi aşağıdaki gibi modellenmiştir: 
$\ln (p \ddot{u})_{i t}=\alpha+\beta_{1} \ln (p \ddot{u})_{i t-1}+\sum_{k=1}^{3} \phi_{k} E k f h_{i t}+\sum_{l=1}^{2} \theta_{l} G e l_{i t}+\sum_{m=1}^{3} \lambda_{m} K r i z_{i t}+\sum_{n=1}^{2} \gamma_{n} G_{i}+\varepsilon_{i t}$

(1) numaralı eşitlikte $\ln (p u ̈) t$ döneminde $i$ ülkesinde faaliyet gösteren sigorta şirketlerinin toplam prim üretimlerinin doğal logaritmasını simgelemektedir. Eşitlik prim üretiminin geçmişe bağlılı̆ını ve sürekliliğini (persistency) yansıtması için dinamik yapıda tanımlanmıştır. Modeldeki açıklayıcı değişkenler, bağımlı değişkenin kendi gecikmesi dışında dört değişkenler vektöründen meydana gelmektedir. Ekfh vektörü; ekonomik faaliyet hacmindeki değişmeleri yansıtan ilgili ülkenin çıktı açığı $(c k t a)$ ve işsizlik oranından (isz) oluşur:

$$
\sum_{k=1}^{2} E k f h_{i t}=\left\{c ̧ k t a_{i t}, i s z_{i t}\right\}
$$

gel vektörü; kişi başına gelir düzeyi $(\ln (k b g))$, kişi başına satın alım gücü $(\ln (k b s a g))$ ve kişi başına tasarruf düzeyi $(\ln (k b t))$ değişkenlerinden meydana gelmektedir:

$$
\sum_{l=1}^{3} g e l_{i t}=\left\{\ln (k b g)_{i t}, \ln (k b s a g)_{i t}, \ln (k b t)_{i t}\right\}
$$

Bireysel sigorta müşterileri için başta hayat sigortası poliçeleri olmak üzere bazı sigorta ürünleri tasarruf aracı olarak algılandığından, kişi başına gelir ve satın alım gücü gibi refahı yansıtan değişkenler yanında kişi başına tasarruflar da dikkate alınmıştır. Tüm bu değişkenlerdeki artışın prim üretimine pozitif etkileri olması beklenmektedir.

(1) numaralı eşitlikteki Krizvektörü, üç değişkenden meydana gelmektedir. İlki ABD'de konut piyasası çöküşüyle başlayıp toparlanma sürecine girilmesiyle sonlandığı varsayılan küresel kriz gölgesidir (kkriz). Bu değişken, 2007-2010 dönemi "1" diğer yıllar "0" olarak tanımlanmıştır. Çünkü ABD'de kriz 2007 ortalarında konut piyasasında başlamış, 2008 Eylül ayında Lehman Brothers yatırım bankasının iflası ile şiddetlenmiş, önce Avrupa'ya ardından dünyanın diğer ülkelerine sıçramıştır. 2010'da ABD'nin krizden çıkmasıyla dünyada da şiddeti azalmıştır. Bununla birlikte Yunanistan gibi bazı Avrupa ülkelerinde etkilerini bu tarihten sonra da sürdürmüştür.
Borç krizi Belçika, Yunanistan, İrlanda, İtalya, İzlanda, Portekiz ve İspanya'da meydana gelmiştir. Ama hem bu ülkelere kaynak sağlayan hem de yakın ekonomik işbirliği içinde olan hemen tüm Avrupa ülkelerini az veya çok etkilemiştir. Dolayısıyla çalışmada borç krizi iki değişkenle temsil edilmiştir. Illki tüm Avrupa ülkelerini (bkrizi'), ikincisi ise sadece krizden doğrudan etkilenen ve adları yukarıda belirtilen ülkeleri (bkrizi) kapsamaktadır. Her iki gölge değişken; 2008'de Lehman Brothers'ın çöküşüyle krizin ABD'den diğer ülkelere yayıldığı ve Avrupa'da genel toparlanmanın 2012'de başladığı kabul edilerek 2008-2012 dönemi "1" ve diğer yıllar "0" olarak tanımlanmıştır:

$$
\sum_{l=1}^{3} k r i z_{i t}=\left\{k k r i z_{i t}, b k r i z i_{i t}^{T}, b k r i z i_{i t}\right\}
$$

Çalışmada dikkate alınan 32 Avrupa ülkesinin $28^{\prime} \mathrm{i} A B$ üyesidir. Diğerlerinin de $A B^{\prime} y e$ giriş sürecinde oldukları söylenebilir. $A B$ üyesi 28 ülkeden 18'i Euro alanına dahildir, yani resmi para birimleri olarak Euro'yu kullanmaktadırlar. Bu alana dahil olan ülkelerin genellikle ekonomik gelişmişlik ve refah düzeyleri diğer birlik üyesi ülkelerin üstündedir. Ancak bu grup içinde yer alan Yunanistan, Portekiz, İspanya, İrlanda gibi bazılarının borç krizine girdikleri ve kamu maliyesi dengelerinin bozuk olduğu gözden uzak tutulmamalıdır. Aynı şekilde İngiltere, Danimarka ve İsveç gibi Euro alanında olmayıp da ekonomik gelişmişlik düzeyleri yüksek birlik üyeleri de vardır. Avrupa'daki bu yapının etkilerinin modele yansıtılabilmesi için $A B$ üyelerini $(A B)$ ve Euro alanına dâhil olan ülkeleri $(E A)$ ifade eden iki gölge değişken daha tanımlanmıştır. Bunlar zamandan bağımsız gölge değişkenlerdir ve bu nedenle sadece ilgili ülkeyi simgeleyen $i$ alt indisi içermektedirler:

$$
\sum_{m=1}^{2} g_{i}=\left\{A B_{i}, E A_{i}\right\}
$$

(1) numaralı eşitlik tüm değişkenleri ve tahmin edilecek katsayıları yansıtacak şekilde aşağıdaki gibi de ifade edilebilir:

$$
\begin{aligned}
\ln (p \ddot{u})_{i t} & =\alpha+\beta_{1} \ln (p \ddot{u})_{i t-1}+\phi_{1} c k t a_{i t}+\phi_{2} i s z_{i t} \\
& +\theta_{1} \ln (k b g)_{i t}+\theta_{2} \ln (k b s a g)_{i t}+\theta_{3} \ln (k b t)_{i t} \\
& +\lambda_{1} k k r i z_{i t}+\lambda_{2} b k r i z_{i t}^{\text {Tüm }}+\lambda_{3} b k r i z_{i t}+\gamma_{1} A B_{i}+\gamma_{2} E A_{i}+\varepsilon_{i t}
\end{aligned}
$$


Analiz edilecek modelin dinamik yapıda olması nedeniyle, tahmin sürecinde alternatiflerine oranla dinamik etkileri daha iyi yansıtan dinamik panel veri yöntemi tercih edilmiştir. Ancak alternatif dinamik panel veri modellerinden hangisinin kullanılacağı önemli bir konudur. Dinamik panel veri modelleri Anderson ve Hsiao'nun (1981) çalışmasına dayansa da, Holtz-Eakin vd. (1988), Arellano ve Bond (1991) gibi araştırmacıların çalışmalarıyla bugünkü haline gelmiştir. Arellano ve Bond (1991) tarafından geliştirilen iki aşamalı genelleştirilmiş momentler yöntemine (generalized method of moment / GMM) dayalı tahmin yaklaşımı bu gibi analizlerde sıkça kullanılmaktadır. Bununla beraber bankacılık ve sigortacılık alanlarındaki daha güncel çalışmalarda Arellano ve Bover (1995) ile Blundell ve Bond (1998) tarafından geliştirilmiş olan sistem dinamik panel veri modellerinin kullanıldığı görülmektedir. Sistem dinamik modeller de, iki aşamalı GMM tahmincisine dayanmakta, ama yapıları itibariyle ilk nesil dinamik modellerden daha üstün tahmin özellikleri taşımaktadır.

Çok sayıda kesiti içeren, ama zaman boyutu nispeten kısa olan veri setleri için sistem dinamik modeller ideal kabul edilmektedir. Arellano-Bond (1991) yöntemi, böyle veri setlerinde eğilimli sonuçlar üretirken, sistem dinamikmodellerbu eğilimsorununu ortadan kaldırarak sağlam sonuçlar vermektedir. Bu yöntemle tutarlı tahminler yapıldığından emin olmak için hem hata terimlerinde ikinci mertebeden ardışık bağlanım (second-order autocorrelation) olmadığını hem de araç değişkenlerin geçerli (instruments validity) olduğunu ispat etmek gerekmektedir. Bunun için sırasıyla ikinci derece ardışık bağlanım olmadığına dair yokluk hipotezini test eden Arellano-Bond testi ve ardından araç değişkenlerin geçerliliğinin sınanması amacıyla Sargan veya Hansen testi uygulanması gerekmektedir (Roodman, 2006, 2008). Çalışmada diagnostik sınamalar sözü edilen testlerle gerçekleştirilecektir. Dinamik modellerin en yalın hali aşağıdaki gibi ifade edilebilir:

$$
\begin{aligned}
& Y_{i t}=\alpha+\sum_{k=1}^{p} \delta_{k} Y_{i t-k}+\beta X_{i t}+u_{i t}+\varepsilon_{i t} \\
& Z=\left\{Y_{i t-1}, Y_{i t-2}, \ldots, Y_{i t-p} ; \Delta Y_{i t-1}, \Delta Y_{i t-2}, \ldots, \Delta Y_{i t-p} ; X_{i t}, D_{i t}\right\}
\end{aligned}
$$

Dinamik modellerde tahmin süreci bir veya iki aşamalı GMM tahmincilerine dayanmaktadır. Bu itibarla dinamik modellerde, (3) numaralı eşitlikte $Z$ matrisi ile gösterilen araç değişkenler seti de söz konusudur. Araç değişkenler bağımlı değişkenin gecikmelerinden ve farkının gecikmelerinden, açıklayıcı değişkenlerden ve gölge değişkenlerden $(D)$ meydana gelebilir. Tahmin sürecinde (3) numaralı modelin birinci farkı alınmakta ve genel olarak aşağıdaki yapıda bir eşitliğin tahmini yapılmaktadır:

$$
\Delta Y_{i t}=\alpha+\sum_{k=1}^{p} \delta_{k} \Delta Y_{i t-k}+\beta \Delta X_{i t}+\Delta u_{i t}+\Delta \varepsilon_{i t}
$$

\subsection{Veri Seti}

Çalışmada $A B$ üyesi olan ve olmayan 32 Avrupa ülkesinin verileri kullanılmıştır. Sigorta şirketlerinin prim üretimi verisi Comite European des Assurances'ın The European Insurance Industry başlıklı raporunun çeşitli sayılarından (2004-2012) derlenmiştir. Söz konusu ülkelere dair GSYiH, işsizlik oranı, bütçe dengesinin GSYiH'ye oranı, sabit fiyatlarla kişi başına gelir ve satın alma gücü gibi makro ekonomik değişkenler ise IMF World Economic Outlook Ekim 2014 raporundan alınmıştır. Çıktı açığı ilgili ülkenin sabit fiyatlarla hesaplanmış GSYiH değerinin kendi Hodrick-Prescott trendinden sapması olarak hesaplanmıştır. Değişkenler ve veri kaynaklarına dair detaylı açıklamalar Tablo 1'de sunulmuştur. Örneklemde 32 Avrupa ülkesinin 1993-2012 dönemi yıllık verileri kullanılmıştır. Dolayısıyla kesit başına gözlem sayısı 20, toplam gözlem sayısı 640'tır.

\subsection{Bulgular}

Analizlerin ilk aşamasında değişkenlerin yapısı analiz edilmiştir. Bu çerçevede sırasıyla tanımsal istatistikler, korelasyon katsayıları ve durağanlık sınamaları yapılmıştır. Değişkenlere dair tanımsal istatistikler Tablo 2'de sunulmuştur. Değişkenlerin tümünün normal dağılmadıkları gözlenmiştir. Çıktı açığı, işsizlik, prim üretimi dağılımları sağa çarpıktır. Çıktı açığının dağılımı dikken, işsizliğin ve prim üretiminkiler nispeten basık bir yapıdadır. Kişi başına gelir ve kişi başına satın alma gücü sola çarpık ve dik bir dağılım göstermektedir. Kişi başına tasarrufların dağılımı ise; kendi ortalamasına nispeten yakın ve oldukça basıktır.

Korelasyon katsayıları matrisi yardımıyla değişkenler arası karşılıklı ilişkiler değerlendirilmiştir. Tablo 3'de sunulan korelasyon katsayıları incelendiğinde; işsizliğin çıktı açığı ve kişi başına tasarruflarla \%30'lar civarında negatif bir ilişkisi olduğu görülmektedir. Kişi başına gelirin sırasıyla kişi başına satın alım gücü ile yaklaşık \%65, kişi başına tasarruflarla \%27, prim üretimi ile yaklaşık \%19 oranlarında pozitif, işsizlikle \%18 oranında negatif bir ilişki içinde olduğu belirlenmiştir. Prim üretiminin kişi başına satın alım gücü ile \%32 
pozitif ve kişi başına tasarruflarla \%36 negatif bir ilişki içinde olduğu dikkati çekmektedir. Kişi başına satın alım gücünün kişi başına tasarruflarla \%16 civarında pozitif bir ilişkisi vardır.

Tablo 1: Değişken Tanımlamaları ve Veri Kaynakları

\begin{tabular}{|c|c|c|}
\hline Değişken & Tanımı & Verilerin Derlendiği Kaynak \\
\hline $\operatorname{Ln}(p \ddot{)})$ & Prim üretiminin doğal logaritması & $\begin{array}{l}\text { Comite European des Assuran-ces'In The } \\
\text { European Insurance, 2004-2012 Industry }\end{array}$ \\
\hline ckta & Çıktı açığı & IMF World Economic Outlook Ekim 2014 \\
\hline isz & İşsizlik oranı & IMF World Economic Outlook Ekim 2014 \\
\hline $\operatorname{Ln}(k b g)$ & Kişi başına gelir düzeyinin doğal logaritması & IMF World Economic Outlook Ekim 2014 \\
\hline Ln(kbsag) & Satın alma gücünün doğal logaritması & IMF World Economic Outlook Ekim 2014 \\
\hline $\operatorname{Ln}(\mathrm{kbt})$ & Kişi başına tasarruf düze-yinin doğal logaritması & IMF World Economic Outlook Ekim 2014 \\
\hline kkriz & Küresel krizi temsil eden gölge değişken ${ }^{3}$ & European Central Bank, Brender vd. $(2012)^{4}$ \\
\hline bkrizi $^{\top}$ & Tüm Avrupa ülkelerinde borç krizini yansıtan gölge değişken ${ }^{3}$ & European Central Bank, Brender vd. $(2012)^{4}$ \\
\hline bkrizi & $\begin{array}{l}\text { Borç krizinden doğrudan etkilenen Avrupa ülkelerini kapsayan } \\
\text { gölge değişken }{ }^{3}\end{array}$ & European Central Bank, Brender vd. (2012) ${ }^{4}$ \\
\hline$A B$ & Avrupa Birliği üyesi ülkeleri yansıtan gölge değişken ${ }^{5}$ & Tarafımızca oluşturulmuştur. \\
\hline EA & $\begin{array}{l}\text { Euro Alanına dahil birlik üyesi ülkeleri yansıtan gölge } \\
\text { değişken }{ }^{5}\end{array}$ & Tarafımızca oluşturulmuştur. \\
\hline
\end{tabular}

(1) 2004 tarihli rapor 1993-2004 dönemi verileri kapsamaktadır.

(2) Sabit fiyatlarla GSYiH'nin kendi Hodrick-Prescott trendinden farkı alınarak hesaplanmaktadır.

(3) Krizleri temsil eden gölge değişkenler, kriz dönemi " 1 " diğer dönemler " 0 " alınarak oluşturulmuştur.

(4) Kriz gölgeleri belirtilen bu kaynaklardan hareketle tarafımızca oluşturulmuştur.

(5) ìlgili gruba dahil ülkeler "1" diğer ülkeler " 0 " alınarak oluşturulmuştur.

Tablo 2: Tanımsal İstatistikler

\begin{tabular}{|l|r|r|r|r|r|r|}
\hline & ckta & isz & Ln(kbg) & Ln(kbsag) & Ln(kbt) & Ln(pu) \\
\hline Mean & -0.1629 & 8.2639 & 10.4406 & 9.9225 & 1.0487 & 9.2028 \\
\hline Median & 0.0000 & 7.6265 & 10.1985 & 10.0874 & 1.0740 & 9.7082 \\
\hline Maximum & 21.9110 & 24.8000 & 15.1796 & 11.4181 & 4.8122 & 22.3286 \\
\hline Minimum & -13.2520 & 0.0000 & 0.0000 & 0.0000 & -1.7136 & 0.0000 \\
\hline Std. Dev. & 3.2881 & 4.3063 & 1.9740 & 1.2193 & 1.5514 & 3.7833 \\
\hline Skewness & 2.1151 & 0.9067 & -0.9354 & -6.4389 & 0.2775 & -0.4208 \\
\hline Kurtosis & 17.5946 & 4.0120 & 10.3826 & 52.7941 & 2.5069 & 4.3560 \\
\hline Jarque-Bera & 6465.1240 & 120.7567 & 1592.6320 & 73627.0800 & 15.3392 & 70.7873 \\
\hline & {$[0.0000]$} & {$[0.0000]$} & {$[0.0000]$} & {$[0.0000]$} & {$[0.0005]$} & {$[0.0000]$} \\
\hline
\end{tabular}

Tablo 3: Korelasyon Katsayıları Matrisi

\begin{tabular}{|r|r|r|r|r|r|r|}
\hline & ckta & İsz & Ln(kbg) & Ln(kbsag) & Ln(kbt) & $\operatorname{Ln}(\mathrm{pu})$ \\
\hline ckta & 1.0000 & -0.3282 & 0.0722 & 0.0524 & 0.0029 & -0.0689 \\
\hline isz & -0.3282 & 1.0000 & -0.1818 & -0.0404 & -0.3003 & -0.0566 \\
\hline Ln(kbg) & 0.0722 & -0.1818 & 1.0000 & 0.6484 & 0.2704 & 0.1913 \\
\hline Ln(kbsag) & 0.0524 & -0.0404 & 0.6484 & 1.0000 & 0.1628 & 0.3257 \\
\hline Ln(kbt) & 0.0029 & -0.3003 & 0.2704 & 0.1628 & 1.0000 & -0.3652 \\
\hline $\operatorname{Ln}(\mathrm{pu})$ & -0.0689 & -0.0566 & 0.1913 & 0.3257 & -0.3652 & 1.0000 \\
\hline
\end{tabular}


Değişkenlerin durağanlıkları Levin, Lin ve Chu (2002) tarafından geliştirilen " $t$ ", Im, Pesaran ve Shin (2003) tarafından geliştirilen "W", Choi (2001) tarafından geliştirilen "ADF-Fisher" panel birim kök testleri ile araştırılmıştır. Sonuçlar Tablo 4'de sunulmaktadır. Çıktı açığı, işsizlik oranı ve kişi başına tasarruf oranı düzey hallerinde durağanken; prim üretimi, kişi başına gelir ve satın alma güçlerinin birinci farklarının durağan olduğu belirlenmiştir.

Analizlerin ikinci aşamasını, Arellano ve Bover (1995) ve Blundell ve Bond'un (1998) çalışmalarına dayanan iki aşamalı sistem dinamik panel veri modellerinin tahmini oluşturmaktadır. 3.1 numaralı alt bölümün sonlarında da belirtildiği gibi sistem dinamik modellerin tasarımı gereği modele dahil edilen değişkenlerin birinci farkları dikkate alınmaktadır.
Dolayısıyla analiz esnasında düzey halleri durağan olmayan değişkenler de durağanlaşmış olacaktır. Bu itibarla düzeyde durağan olmayan değişkenlerin modele eklenirken farkları alınmamıştır.

Çalışmada tahmin edilen modellerin düzey denklemleri için araç değişken olarak sadece bağımlı değişkenin ilk gecikmesi ile sabit terim kullanılmıştır. Farkı alınmış denklemlerde de, bağımlı değişkenin ilk gecikmesinin yer alması tercih edilmiştir. Bunun başlıca nedeni bağımlı değişkenin geçmişe bağlılığının, ama özellikle süreklilik eğiliminin gözlemlenebilmesidir. Sayılanlara ek olarak tahmin sürecinde kullanılan yazılım (Stata 13), modellerin farkı alınmış denklemlerine standart araç değişken olarak bağımsız değişkenlerin birinci farklarını da eklemiştir.

Tablo 4: Panel Birim Kök Testleri

\begin{tabular}{|c|c|c|c|c|c|c|c|c|c|}
\hline Düzey & Test & p Değeri & Gecikme*** & Test & p Değeri & Gecikme*** & Test & p Değeri & Gecikme*** \\
\hline & \multicolumn{3}{|c|}{ In(prim üretimi) } & \multicolumn{3}{|c|}{ Çıktı Açığı } & \multicolumn{3}{|c|}{ İşsizlik } \\
\hline Levin, Lin \& Chu $t^{*}$ & -2.33371 & 0.0098 & 1 & -3.7992 & 0.0001 & 3 & -2.17358 & 0.0149 & 4 \\
\hline Im, Pesaran and Shin W-stat** & -0.26413 & 0.3958 & 1 & -5.8357 & 0.0000 & 3 & -2.84793 & 0.0022 & 4 \\
\hline ADF - Fisher Chi-square** & 63.0429 & 0.5104 & 1 & 109.0240 & 0.0000 & 3 & 113.005 & 0.0002 & 4 \\
\hline \multirow[t]{2}{*}{ PP - Fisher Chi-square ${ }^{* *}$} & 63.9793 & 0.4772 & 1 & 74.4887 & 0.0015 & 3 & 72.8468 & 0.2099 & 4 \\
\hline & \multicolumn{3}{|c|}{ In(K.B. Gelir) } & \multicolumn{3}{|c|}{ In(K.B. Satın Alma Gücü) } & \multicolumn{3}{|c|}{ In(K.B. Tasarruf) } \\
\hline Levin, Lin \& Chu $t^{*}$ & -7.7041 & 0.0000 & 3 & -6.2782 & 0.0000 & 4 & -14.0283 & 0.0000 & 3 \\
\hline Im, Pesaran and Shin W-stat** & -0.7290 & 0.2330 & 3 & 0.2077 & 0.5823 & 4 & -7.76248 & 0.0000 & 3 \\
\hline ADF - Fisher Chi-square ${ }^{* *}$ & 75.2465 & 0.1588 & 3 & 60.6751 & 0.5948 & 4 & 363.761 & 0.0000 & 3 \\
\hline PP - Fisher Chi-square ${ }^{* *}$ & 56.3662 & 0.7402 & 3 & 142.4800 & 0.0000 & 4 & 337.557 & 0.0000 & 3 \\
\hline \multicolumn{10}{|l|}{ 1. Fark } \\
\hline & \multicolumn{2}{|c|}{$\mathrm{d}(\operatorname{In}($ prim Üret.)) } & & \multicolumn{3}{|c|}{ d(çkt.a.) } & \multicolumn{3}{|c|}{$\mathrm{d}(\mathrm{isz})}$. \\
\hline Levin, Lin \& Chu $t^{*}$ & -25.0817 & 0.0000 & 1 & -12.1812 & 0.0000 & 4 & -10.9322 & 0.0000 & 1 \\
\hline Im, Pesaran and Shin W-stat ${ }^{* *}$ & -19.3657 & 0.0000 & 1 & -11.8049 & 0.0000 & 4 & -10.2061 & 0.0000 & 1 \\
\hline ADF - Fisher Chi-square ${ }^{* *}$ & 466.0430 & 0.0000 & 1 & 205.1690 & 0.0000 & 4 & 235.0850 & 0.0000 & 1 \\
\hline \multirow[t]{2}{*}{ PP - Fisher Chi-square ${ }^{* *}$} & 769.8320 & 0.0000 & 1 & 259.9090 & 0.0000 & 4 & 267.1660 & 0.0000 & 1 \\
\hline & \multicolumn{3}{|c|}{$\mathrm{d}(\ln ($ K.B. Gelir $))$} & \multicolumn{3}{|c|}{$\mathrm{d}(\ln ($ K.B.S.A.G. $))$} & \multicolumn{3}{|c|}{$\mathrm{d}(\ln ($ K.B.T. $))$} \\
\hline Levin, Lin \& Chu t* & -10.0232 & 0.0000 & 4 & 2.2726 & 0.9885 & 4 & -11.1347 & 0.0000 & 3 \\
\hline Im, Pesaran and Shin W-stat** & -9.5922 & 0.0000 & 4 & -8.6646 & 0.0000 & 4 & -16.6517 & 0.0000 & 3 \\
\hline ADF - Fisher Chi-square** & 208.7550 & 0.0000 & 4 & 190.1530 & 0.0000 & 4 & 364.8960 & 0.0000 & 3 \\
\hline PP - Fisher Chi-square ${ }^{* *}$ & 224.1160 & 0.0000 & 4 & 446.9960 & 0.0000 & 4 & 816.7320 & 0.0000 & 3 \\
\hline
\end{tabular}

(*) Ho: Genel bir birim kök süreci vardır. (**) Ho: Münferit birim kök süreçleri vardır. (***) Schwarz bilgi kriterine göre otomatik olarak belirlenmiştir. 
Tablo 5: Sistem Dinamik Panel Veri Tahminleri

\begin{tabular}{|c|c|c|c|c|c|c|c|c|c|}
\hline & \multicolumn{2}{|c|}{ [1] } & & \multicolumn{2}{|c|}{$[2]$} & & \multicolumn{2}{|c|}{ [3] } & \\
\hline & Katsayı & z Testi & & Katsayı & z Testi & & Katsayı & z Testi & \\
\hline Sabit & 8.762 & 7.110 & $* * *$ & 7.813 & 17.560 & $* * *$ & 7.745 & 40.660 & $* * *$ \\
\hline $\ln (p \ddot{)})(-1)$ & 0.716 & 182.400 & $* * *$ & 0.736 & 284.880 & $* * *$ & 0.743 & 301.970 & $* * *$ \\
\hline çkta & -0.005 & -1.260 & & -0.031 & -10.010 & $* * *$ & -0.018 & -7.620 & $* * *$ \\
\hline isz & -0.016 & -1.640 & $*$ & -0.045 & -7.500 & $* * *$ & -0.037 & -6.860 & $* * *$ \\
\hline $\ln (\mathrm{kbg})$ & 0.191 & 1.240 & & -0.020 & -0.150 & & & & \\
\hline In(kbsag) & -0.735 & -7.250 & $* * *$ & -0.492 & -4.660 & $* * *$ & -0.524 & -26.210 & $* * *$ \\
\hline $\ln (k b t)$ & 0.156 & 1.160 & & 0.128 & 1.200 & & 0.186 & 3.470 & $* * *$ \\
\hline kkriz & 0.006 & 0.410 & & -0.068 & -5.610 & $* * *$ & -0.074 & -7.690 & $* * *$ \\
\hline bkrizi $^{\mathrm{tüm}}$ & 0.062 & 0.110 & & -0.063 & -3.390 & $* * *$ & -0.039 & -2.460 & $* *$ \\
\hline bkrizi & -0.398 & -0.170 & & & & & & & \\
\hline$A B$ & -2.883 & -1.450 & & & & & & & \\
\hline EA & 2.881 & 1.090 & & & & & & & \\
\hline \multicolumn{10}{|l|}{ Wald Testi: } \\
\hline Ki Kare & 207513.67 & {$[0.0000]$} & & 264800.2 & {$[0.0000]$} & & 772148.8 & {$[0.0000]$} & \\
\hline \multicolumn{10}{|l|}{ Sargan Testi: } \\
\hline Ki Kare & 29.4208 & [1.0000] & & 29.6117 & [1.0000] & & 30.8091 & [1.0000] & \\
\hline \multicolumn{10}{|l|}{ Arellano-Bond Testi: } \\
\hline & z & p Değeri & & z & p Değeri & & z & p Değeri & \\
\hline $\mathrm{AR}(1)$ & -2.0088 & 0.0446 & & -2.0052 & 0.0449 & & -2.0080 & 0.0446 & \\
\hline $\operatorname{AR}(2)$ & 1.0703 & 0.2845 & & 1.0850 & 0.2779 & & 1.0833 & 0.2787 & \\
\hline
\end{tabular}

$\left.\left({ }^{* * *}\right),\left(^{* *}\right),{ }^{*}\right)$ simgeleri z testlerinin sırasıyla $\% 1, \% 5$ ve $\% 10$ düzeyinde anlamlı olduklarını göstermektedir.

Sistem dinamik panel veri tahminlerinin sonuçları Tablo 5'de sunulmaktadır. Yapısı 3.1 numaralı alt bölümde açıklanan (2) numaralı model tahmin edilmiştir. Tablo 5'de [1] olarak belirtilen orijinal modelden istatistik olarak anlamsız katsayı değerleri veren değişkenler çıkartılarak [2] ve [3] numaralı tahminler elde edilmiştir. En anlamlı katsayı değerlerine [3] numaralı tahminde ulaşılmıştır. Ancak $\ln (\mathrm{kbg})$ ve $\ln (k b t)$ gibi bazı önemli değişkenler anlamlı sonuç vermedikleri halde [2] numaralı tahmin yine de sunulmuştur. Bunun nedeni anlamsız bulunan diğer değişkenler çıkartıldıktan sonra bile, sözü edilen iki önemli değişkenin anlamlı katsayı değeri vermediğinin vurgulanmak istenmesidir.

Tüm tahminlerin tanı koyma sınamalarını (diagnostic tests) geçtikleri görülmektedir. Wald testleri modellerin genel anlamlılıklarının yüksek olduğunu göstermektedir. Araç değişkenler setinin geçerliliğini sınayan Sargan testinin sonuçları, tüm modellerde araç değişken seçiminin doğru olduğunu göstermektedir. Modellerin geçerliliğinin bir başka koşulu da, kalıntıların ikinci dereceden ardışık bağlanım sorunu göstermediklerinden emin olunmasıdır. Bu amaçla Arellano-Bond testi kullanılmaktadır. Birinci farkları alınmış model kalıntılarına uygulanan birinci $(A R(1))$ ve ikinci mertebeden $(A R(2))$ ardışık bağlanımı sınayan bu testin en azından farkı alınmış kalıntıların ikinci mertebeden ardışık bağlanım sorunları bulunmadığını göstermesi beklenir. ${ }^{4}$ Elde edilen sonuçlar, kalıntıların hem birinci hem de ikinci mertebeden ardışık bağlanımları olmadığını göstermektedir. Tüm bu sonuçlardan kullanılan GMM tahmincisinin etkin olduğu anlaşılmaktadır.

Tahminlerin anlamlı katsayı değerleri incelendiğinde, Avrupa'da sigorta şirketlerinin prim üretimlerinin kendi geçmiş değerlerine pozitif bir bağlılık gösterdikleri, 0.71 ile 0.74 civarındaki katsayı tahminlerinin güçlü bir süreklilik (persistency) olgusuna 
işaret ettiği anlaşılmaktadır. Çıktı açı̆̆ı ve işsizlik gibi ekonomik faaliyet hacmindeki değişmeleri gösteren makro ekonomik değişkenlerin prim üretimini negatif olarak etkilediği belirlenmiştir. Satın alma gücü prim üretimini negatif, kişi başına tasarruflar ise pozitif etkilemektedir. Bunlar söz konusu değişkenler arası ilişkileri yansıtan ve Tablo 3'de sunulan korelasyon katsayıları ile çelişmektedir. Değinilen çelişki, ardı ardına meydana gelen ve Avrupa ülkelerini ciddi oranda sarsan küresel kriz ve borç krizine bağlanabilir. Krizleri yansıtan gölge değişkenlerin anlamlı katsayı değerleri vermesi de bu tezi güçlendirmektedir.

Tahminler hem küresel kriz hem de tüm Avrupa ülkeleri bazında borç krizinin prim üretimindeki değişmeleri güçlü ve negatif bir şekilde açıkladığını göstermektedir. Ancak borç krizinden en fazla etkilenen Avrupa ülkelerini yansıtan gölge değişken anlamlı bulunmamıştır. Bu incelenen örneklemdeki 32 ülkenin 28'nin $A B$ üyesi olmasına ve ileri düzeyde bir bütünleşme sürecinde olmalarına bağlanabilir. Ancak $A B$ üyesi ve Euro alanı üyesi Avrupa ülkelerini yansıtan gölge değişkenlerin anlamsız katsayı değerleri vermesi bu savı zayıflatmaktadır. Etkileşimli krizlerin prim üretimini olumsuz etkiledikleri açıktır. Bununla birlikte krizlerin Avrupa'nın hangi ülkelerinde daha etkili olduğu ve krizden daha fazla etkilenen ülkelerde her iki faktörün sigorta primlerine hangi ölçüde yansıdığı belirsizdir.

Krizlerin Avrupa ekonomilerini durgunluğa ittiği, işsizlik oranlarının arttığı, insanların gelirlerinin ve satın alım güçlerinin azaldığı bilinmektedir. Bu zincirleme etkilerin bir sonucu olarak refah düzeyi yüksek ve toplumda yerleşik bir sigorta bilinci olan Avrupa ülkelerinde bile, sigorta talebinin ve prim üretiminin düştüğü gözlenmiştir. Gelişmiş ekonomilerde finans sektöründeki şokların sigorta piyasasını sadece yatırım portföyleri bakımından değil, kaynak tedarik bakımından da sarsacağı görülmektedir. Yüksek ve tabana yayılmış refah veya sigorta bilincinin fazla oluşu dahi bu etkileri engelleyememektedir.

\section{SONUÇ}

Çalışmada Avrupa ülkeleri örneğinden hareketle gelişmiş ülkelerde sigorta şirketlerinin prim üretimlerinin gelire dayalı belirleyicileri araştırılmıştır. Ayrıca 2008'de meydana gelen küresel kriz ve bunun da etkisiyle Avrupa'da patlak veren borç krizinden yola çıkılarak; refah düzeyinin yüksek ve topluma yaygın olduğu, güçlü bir sigorta bilinci olan ülkelerde sigorta şirketlerinin prim üretimlerinin krizlerden nasıl etkilendiği de incelenmiştir. Avrupa Birliği'ne üye olan ve olmayan 32 ülkenin verileri kullanılarak sistem dinamik panel veri modelleriyle analizler yapılmıştır.

Ulaşılan bulgular sigorta şirketlerinin prim üretimlerinin kişi başına satın alma gücü ve kişi başına tasarruf gibi gelir temelli belirleyicilerden etkilendiğini göstermektedir. Ekonomik faaliyet hacmindeki değişmeleri yansıtan ve insanların gelir düzeyleri, tasarruf eğilimleri ve harcama davranışları üzerinde önemli etkileri olan çıktı açığı ve işsizlik oranı gibi değişkenlerin de prim üretimini açıkladıkları görülmüştür. Bir başka bulgu da, sigorta şirketlerinin prim üretimlerinin küresel krizden ve borç krizinden etkilendiği yönündedir. Beklenenin aksine satın alma gücünün prim üretimi ile negatif bir ilişki içinde olduğu gözlenmiştir. Bu durum analiz edilen örneklemde krizlerin derin etkisine bağlanabilir. Ardı ardına meydana gelen ve Avrupa merkezli tüm finans kuruluşları gibi sigorta şirketlerini de derinden etkileyen krizler, Avrupa'nın genelinde ekonomilerin yavaşlamasına neden olmuştur. İşsizlik oranlarındaki artışın da eşlik ettiği bu tablo, insanların ortalama gelir düzeylerini ve satın alım güçlerini düşürmüş ve sigorta ürünlerine olan talebin azalmasına neden olmuştur. Bu gelişmeler, finansal ve ekonomik krizlerin gelişmiş ülkelerde neredeyse zorunlu bir ihtiyaç olarak görülen sigorta ürünleri talebine ve sigorta şirketlerinin fon kaynaklarına yaptıkları olumsuz etkileri göstermesi açısından önemlidir. Elbette daha kesin yargılarda bulunmak için kapsamlı veri setlerine dayanan daha fazla sayıda deneysel yapılması gerekmektedir.

\section{SON NOTLAR}

${ }^{1}$ Gius (1998), SEK regresyonu ile ABD'de yapılan yasal reformların tıbbi uygulama hataları sigortası primlerine olan etkilerini araştırmıştır. Bazı reformların primler üzerinde etkili olduğu, bu bağlamda bireysel ve eyalet düzeyindeki etkilerin önemli belirleyiciler olarak öne çıktıkları belirlenmiştir. Benson ve Marks (2011) belediye borçlanma kağıtlarına uygulanan sigortanın belirleyicilerini ele almaktadır. Risk ve prim üretimi arasındaki ilişkiyi analiz etmektedir. Moldogaziev ve Johnson'un (2011) çalışması da belediye borçlanma kağıtlarına yapılan sigortaları ele almaktadır. 2007-2008 finansal krizi esnasında bu tür poliçelerin primlerinin piyasanın durumuna dair sinyalleri barındırdığı belirlenmiştir. 
2 Örneğin Hwang ve Gao'nun (2003) Çin'e üzerine yaptıkları çalışma sigorta talebinin eğitim düzeyi, sosyal yapıdaki değişim ve başarılı ekonomik reformlardan pozitif etkilendiğini, yüksek enflasyondan ise olumsuz etkilendiğini göstermiştir.

${ }^{3}$ Malafronte vd. (2014), Avrupa'da faaliyet gösteren sigorta şirketlerinin yıllık raporlarının anlaşılabilirlik düzeyi üzerinde borç krizinin etkilerini araştırmıştır. Bijlsma ve Vermeulen (2015) ise, Hollanda merkezli sigorta şirketlerinin kriz döneminde riskli varlıklardan güvenli varlıklara geçiş süreçlerini ele almıştır.

${ }^{4}$ Dinamik panel veri modellerinde birinci mertebeden ardışık bağlanım olması beklenen biri durumdur ve önemli değildir. Önemli olan ikinci mertebeden bu sorunun olmamasıdır. İkinci mertebeden ardışık bağlanım sorunu olmayan modeller geçerli veya uygun modellerdir (Tatoğlu, 2013:101-102). Kimi zaman bazı bilim çevrelerinde kalıntılarda birinci derece ardışık bağlanım olması ve ikinci derece olmaması bir gerek şart gibi ifade edilmektedir. Ancak asında sadece ikinci derece ardışık bağlanım olmaması gerek şarttır.

\section{KAYNAKLAR}

Alhassan, A. L., ve Biekpe, N. (2016) "Determinants of Life Insurance Consumption in Africa", Research in International Business and Finance, 37: 17-27.

Anderson T., ve Hsiao, C. (1981) "Estimation of Dynamic Models with Error Components", Journal of American Statistical Association, 76(375): 598-606.

Arellano, M. (2005) Panel Data Econometrics: Advanced Texts in Econometrics, Oxford University Press.

Arellano, M ve Bond, S. (1991) "Some Tests of Specification for Panel Data: Monte Carlo Evidence and an Application to Unemployment Equations", Review of Economic Studies, 58: 277-297.

Arellano, M. ve Bover, O. (1995) "Another Look at the Instrumental Variable Estimation of Error-Components Models", Journal of Econometrics, 68(1): 29-51.

Bagus, P. (2011) “The Eurosystem: Costs and Tragedies", Institution in Crisis: European Perspectives on Recession içinde, Ed. D. Howen, Cheltehham, UK: Edward Elgar Publishing, 117-141.

Beck, T., ve Webb, I.. (2002) "Determinants of Life Insurance Consumption across Countries", World Bank Policy Research Working Papers, March.

Benson, E. D. ve Marks, B. D. (2011) "Determinants of Private Sector Insurance Premiums on Municipal Debt Insurance", Municipal Finance Journal, 32(3), 1-18.

Bijlsma, M. ve Vermeulen, R.. (2015) "Insurance Companies' Trading Behaviour during the European Sovereign Debt Crisis: Flight Home or Flight to Quality?" DeNederlandscheBank Working Papers, No. 468, March.

Blundell, R. ve Bond, S. (1998) "Initial Conditions and Moment Restrictions in Dynamic Panel Data Models", Journal of Econometrics, 87(1): 115-143.

Brender, A., Pisani, F. ve Gagna, E. (2012). The Sovereign Debt Crisis: Placing A Curb on Growth, Centre for European Policy Studies, Brussels.
Choi, I. (2001), "Unit Root Tests for Panel Data”, Journal of International Money and Finance, 20: 249-272.

Curak, M., Dzaja, I., ve Pepur, S.. (2013) "The Effect of Social and Demographic Factors on Life Insurance Demand in Croatia", International Journal of Business and Social Science, 4(9), 65-72.

Cusack, J. (2012). "Eurozone Exposure - The Debt Crisis Impact on (Re)Insurers", Aspen Opinion, 07 February.

Düll, R., König, F. ve Ohls, J. (2015). "On the Exposure of Insurance Companies to Sovereign Risk - Portfolio Investments and Market Forces", Deutsche Bundesbank, Discussion Papers, No. 34/2015.

Enroljas, G. ve Sentis, P. (2008) "The Main Determinants of Insurance Purchase: An Empirical Study on Crop Insurance Policies in France", Lameta Research Papers, No. DR2008-06.

ESRB. (2015)"Report on Systemic Risk in the EU Insurance Sector", European Systemic Risk Board, European System of Financial Supervision, December.

Gius, Mark P. (1998) "Using Panel Data to Estimate the Determinants of Medical Malpractice Insurance Premiums", Applied Economic Letters, 5(1): 37-39.

Gius, M. P. (2010) "An Analysis of the Health Insurance Coverage of Young Adults", International Journal of Applied Economics, 7(1): 1-17.

Guerineau, S. ve Sawadogo, R.. (2015) "On the Determinants of Life Insurance Development in SubSaharan Africa: The Role of the Institutions Quality in the Effect of Economic Development", HAL Archives Papers, No. 001178838, July.

Hammond, J.D., Houston, David B., ve Melander, Eugene R. (1967) "Determinants of Household Life Insurance Premium Expenditures: An Empirical Investigation", Journal of Risk an Insurance, 34(3): 397-408. 
Holtz-Eakin, D., Newey, W., ve Rosen, H.S. (1988) "Estimating Vector Autoregressions with Panel Data", Econometrica, 56(6): 1371-1395.

Hussels, S., Ward, D., ve Zurbruegg, R.. (2005)"Stimulating the Demand for Insurance", Risk Management and Insurance Review, 8(2): 257-278.

Hwang, T, ve Gao, S. (2003) "The Determinants of the Demand for Life Insurance in an Emerging Economy The Case of China", Managerial Finance, 29(5-6): 82 - 96.

Ibok, N. I. (2012) "Socio-Economic and Demographic Determinants of Health Insurance Consumption", Canadian Social Science, 8(5): 58-64.

Ibiwoye, A., Ideji, J. O. ve Oke, B. O. (2010) "The Determinants of Life Insurance Consumption in Nigeria: A Cointegration Approach", International Journal of Academic Research, 2(4): 351-358.

Im, K.S., Pesaran, M.H. and Shin, S. (2003), "Testing for Unit Roots in Heterogeneous Panels", Journal of Econometrics, 115(1): 53-74.

IMF. (2016) "The Insurance Sector - Trends and Systemic Risk Implications", Global Financial Stability Report: Potent Policies for A Successful Normalization, IMF, April. Impawido, G. ve Tower, I.. (2009) "How The Financial Crisis Affects Pensions and Insurance and Why The Impacts Matter", IMF Working Papers, No. WP/09/151, July.

Jakovcevic, D. ve Zaja, M. M. (2014)“Underwriting Risks as Determinants of Insurance Cycles: Case of Croatia", International Journal of Social, Behavioral, Educational, Economic, Business and Industrial Engineering, 8(5): 1251-1258.

Kjosevski, J. (2012) "The Determinants of Life Insurance Demand in Central and Southeastern Europe", International Journal of Economics and Finance, 4(3): 237-247.

Klein, R. W., Ma, G., Ulm, E. R., Wang, S., Wei, X., ve Zanjani, G.. (2009) The Financial Crisis and Lessons for Insurers, Socaity of Actuaries.

Kocovic, J., Antic, T. R., ve Jovovic, M. (2011) "The Impact of The Global Financial Crisis on The Structure of Investment Portfolios of Insurance Companies", Economic Anals, 56(191): 143-161.

Lee, S.-J., Kwon, S.-I., ve Chung, S. Y. (2010)“Determinants of Household Demand for Insurance:The Case of Korea", The Geneva Papers, 35: S82-S91.

Levin, A., Lin C. ve Chu, C.J. (2002), "Unit Root Tests in Panel Data: Asymptotic and Finite-Sample Properties", Journal of Econometrics, 108(1): 1-24.

Liedtke, P. M., ve Schanz, K.U. (2010) "The Global Financial Crisis and the Insurance Industry Frequently
Asked Questions", SC9 Insurance and Finance, The Geneva Association.

Luciano, E., Outreville, F., ve Rossi, M. (2015) "Life Insurance Demand: Evidence from Italian Households, A Microeconomic View and Gender Issues", Nestpar Discussion Papers, No. DP05/2015-010.

Malafronte, I., Porzio, C. ve Starita, M. G. (2014) "Disclosure Practices and Financial Crisis: Empirical Evidences in the European Insurance Industry", SSRN Paper, No. 2374688, June 4.

Moldogaziev, T. T. Ve Johnson, C. L. (2011) "The Determinants of Bonds Insurance Premium", Indiana University School of Public and Environmental Affairs, Reseach Papers, No. 2011-03-06.

Needleman, P., Rastogi, R., and Murray, C. (2012) "Managing Insurers Through the Eurozone Crisis: An Unfolding Story", Emphasis, No. 1: 2-7.

Reinhart, C.M. ve Rogoff, K.S. (2013) "Financial and Sovereign Debt Crises: Some Lessons Learned and Those Forgotten", IMF Working Papers, No. WP/13/266, December.

Roodman, D. (2006). "How to Do xtabond2: An Introduction to "Difference" and "System" GMM in Stata", Center for Global Development Working Papers, No:103, December.

Roodman, D. (2008). “A Note on the Theme of Too Many Instruments", Center for Global Development Working Papers, No: 125, May.

Sarkodie, E. E. ve Yusif, H. M. (2015) “Determinants of Life Insurance Demand, Consumer Perspective - A Case Study of Ayeduase-Kumasi Community, Ghana", Business and Economics Journal, 6(3): 1-4.

Schich, S. (2009) "Insurance Companies and the Financial Crisis", OECD Financial Market Trends, No. 2009/2, October: 1-31.

Schich, S. (2010) "The Role of Insurance in the Recent Financial Crisis", Insurance Markets and Companies: Analyses and Actuarial Computations, 1(1): 45-53.

Tamura, K. ve Tabakis, E. (2013) "The Use of Credit Claims as Colleteral for Eurosystem Credit Operations", European Central Bank Occasional Paper Series, No. 148, June.

Tatoğlu, F. Y. (2013) İleri Panel Veri Analizi: Stata Uygulamalı, 2. Baskı, İstanbul: Beta Yayınevi.

Willie, M.M. (2015) "An Analysis of the Healthcare Premium Determinants Using Mixed Models", Health Systems and Policy Research, 2(1-3): 1-8.

Wilson, T.C. (2013) "Risk Management in the Face of Risky Sovereign Debt: Four Observations", BIS Papers, No. 72. 
Ek Tablo 1: Literatürdeki Deneysel Çalışmaların Kullandıkları Örneklemler ve Analiz Yöntemleri*

\begin{tabular}{|c|c|c|}
\hline Yazarlar & Örneklem & Analiz Yöntemi \\
\hline Hammond vd. (1967) & $\begin{array}{l}A B D, 1953-1962 \text {, hayat sigorta prim } \\
\text { verileri }\end{array}$ & $\begin{array}{l}\text { Kesitsel regresyon ve çok değişkenli regresyon } \\
\text { modelleri }\end{array}$ \\
\hline Beck ve Webb (2003) & $\begin{array}{l}\text { 1961-2000 döneminde } 68 \text { ülkeden } \\
\text { derlenen veriler }\end{array}$ & Doğrusal panel regresyon modeli \\
\hline Enjolras ve Sentis (2008) & $\begin{array}{l}\text { Fransa, 2002-2005 dönemi, tarımsal ürün } \\
\text { sigortaları }\end{array}$ & Lojistik regresyon modeli \\
\hline Klein vd. (2009) & $\begin{array}{l}\text { ABD, 1987-2010 dönemi, konut sigortası } \\
\text { teminatları }\end{array}$ & Vektör hata düzeltme modeli \\
\hline Gius (2010) & $\begin{array}{l}\text { ABD'de } 2008 \text { yılı için Afro-Amerikan } \\
\text { gençler için sağlık sigortası verileri }\end{array}$ & Çok değişkenli regresyon modeli \\
\hline Ibiwoye vd. (2010) & Nijerya, 1970-2005, hayat sigortası verileri & Eşbütünleşme ve Hata düzeltme modeli \\
\hline Lee vd. (2010) & $\begin{array}{l}\text { Güney Kore, 2005, hane halkının sigorta } \\
\text { talebi üzerine anket verileri }\end{array}$ & Tobit modeli \\
\hline $\begin{array}{l}\text { Moldogaziev ve Johnson } \\
(2011)\end{array}$ & $\begin{array}{l}\text { Texas, ABD, 1999-2009 tahvil sigorta } \\
\text { primleri }\end{array}$ & Çok değişkenli regresyon modeli \\
\hline Ibok (2012) & Nijerya, 2012, hayat sigortası anket verileri & Çok değişkenli regresyon modeli \\
\hline Kjosevski (2012) & $\begin{array}{l}14 \text { Orta ve Güney Doğu Avrupa ülkesi, } \\
1998-2010 \text { hayat sigortası verileri }\end{array}$ & $\begin{array}{l}\text { Panel birim kök testleri ve doğrusal panel veri } \\
\text { modeli }\end{array}$ \\
\hline Curak vd. (2013) & $\begin{array}{l}\text { Hırvatistan, } 2013 \text { hayat sigortası anket } \\
\text { verileri }\end{array}$ & Hipotez testle \\
\hline Jakovcevic ve Zaja (2014) & $\begin{array}{l}\text { Hırvatistan,2000-2012 dönemi üçer aylık } \\
\text { hayat dışı branşlara ait sigorta verileri }\end{array}$ & Vektör ardışık bağlanım (VAR) modeli \\
\hline Malafonte vd. (2014) & $\begin{array}{l}\text { Avrupa, } 2005 \text {-2010 dönemi } 47 \text { sigorta } \\
\text { şirketinin risk verileri }\end{array}$ & Doğrusal panel regresyon modeli \\
\hline $\begin{array}{l}\text { Bijlsma ve Vermeulen } \\
(2015)\end{array}$ & $\begin{array}{l}\text { Avrupa, 2006-2013 dönemi } 60 \text { sigorta } \\
\text { şirketinin üçer aylık portföy verileri }\end{array}$ & $\begin{array}{l}\text { Doğrusal panel regresyon ve sabit etkiler } \\
\text { modelleri }\end{array}$ \\
\hline $\begin{array}{l}\text { Guerineau ve Sawadogo } \\
\text { (2015) }\end{array}$ & $\begin{array}{l}20 \text { Sahra altı Afrika ülkesinin 1996-2011 } \\
\text { dönemi hayat sigortası verileri }\end{array}$ & $\begin{array}{l}\text { Araç değişkenler ve genelleştirilmiş momentler } \\
\text { (IV-GMM) tahmincisine dayalı doğrusal panel } \\
\text { veri modelleri }\end{array}$ \\
\hline Luciano (2015) & $\begin{array}{l}\text { İtalya, } 2012 \text { gelir ve hane halkı anketinden } \\
\text { derlenen hayat sigortası verileri }\end{array}$ & Probit ve Tobit modelleri \\
\hline Sarkodie ve Yusif (2015) & $\begin{array}{l}\text { Gana, 2015, } 256 \text { yerleşim yerinden } \\
\text { rastgele örnekleme ile derlenen veriler }\end{array}$ & Lojistik regresyon modeli \\
\hline Willie (2015) & $\begin{array}{l}\text { Güney Afrika, 2009-2013 dönemi sağlık } \\
\text { sigortası verileri }\end{array}$ & Doğrusal karma model (panel veri) \\
\hline $\begin{array}{l}\text { Alhassan ve Biekpe } \\
\text { (2016) }\end{array}$ & $\begin{array}{l}31 \text { Afrika ülkesi, } 2006-2010 \text { dönemi, hayat } \\
\text { sigortası tüketimi verileri }\end{array}$ & Doğrusal ve dinamik panel veri modelleri \\
\hline
\end{tabular}

(*) Hussels vd. (2005), Impavido ve Tower(2009), Schich (2009, 2010), Liedtke ve Schanz (2010), Kocovic vd. (2011), Needleman vd. (2012) gibi araştırmacıların çalışmaları ekonometrik analizlere dayanmadığından, tabloda bunlara yer verilmemiştir.

Ek Tablo 2: GSYiH (Sabit Fiyatlarla, \% Değişim)

\begin{tabular}{|l|l|l|l|l|l|l|l|l|l|l|l|l|l|l|l|}
\hline & 2000 & 2001 & 2002 & 2003 & 2004 & 2005 & 2006 & 2007 & 2008 & 2009 & 2010 & 2011 & 2012 & 2013 & 2014 \\
\hline Euro Alanı & 3.823 & 2.131 & 0.967 & 0.664 & 2.303 & 1.672 & 3.232 & 3.014 & 0.423 & -4.52 & 2.091 & 1.547 & -0.907 & -0.256 & 1.171 \\
\hline Avrupa Birliği & 3.915 & 2.341 & 1.453 & 1.528 & 2.671 & 2.268 & 3.584 & 3.321 & 0.644 & -4.293 & 2.104 & 1.738 & -0.396 & 0.296 & 1.704 \\
\hline
\end{tabular}

Kaynak: International Monetary Fund, World Economic Outlook Database, April 2017. 
Ek Tablo 3: Kamu Kesimi Net Borcu (GSYiH'nin Yüzdesi)

\begin{tabular}{|l|l|l|l|l|l|l|l|l|l|l|l|l|l|l|l|}
\hline & 2000 & 2001 & 2002 & 2003 & 2004 & 2005 & 2006 & 2007 & 2008 & 2009 & 2010 & 2011 & 2012 & 2013 & 2014 \\
\hline Euro Alanı & 47.05 & 46.97 & 47.28 & 48.65 & 48.84 & 49.07 & 47.43 & 45.06 & 46.68 & 54.10 & 58.03 & 62.62 & 65.94 & 68.08 & 68.37 \\
\hline Avrupa Birliği & 43.71 & 44.02 & 44.33 & 44.94 & 45.55 & 46.16 & 44.45 & 42.30 & 46.24 & 50.19 & 58.08 & 60.76 & 63.83 & 65.60 & 66.15 \\
\hline
\end{tabular}

Kaynak: International Monetary Fund, World Economic Outlook Database, April 2017.

Ek Tablo 4: Avrupa Birliği'nde Prim Üretiminin GSYiH'ye Oranı (\%)

\begin{tabular}{|l|c|c|c|c|c|c|c|c|c|c|c|c|}
\hline & 2004 & 2005 & 2006 & 2007 & 2008 & 2009 & 2010 & 2011 & 2012 & 2013 & 2014 & 2015 \\
\hline Toplam Prim Üretimi & 7.9 & 8.1 & 8.3 & 8.4 & 7.6 & 8.1 & 8.0 & 7.5 & 7.4 & 7.5 & 7.6 & 7.4 \\
\hline Hayat Sigortası & 4.8 & 5.1 & 5.2 & 5.5 & 4.7 & 5.0 & 4.9 & 4.5 & 4.4 & 4.5 & 4.6 & 4.5 \\
\hline Hayat Dışı Sigortalar & 2.5 & 2.4 & 2.3 & 2.2 & 2.2 & 2.3 & 2.3 & 2.2 & 2.2 & 2.2 & 2.2 & 2.1 \\
\hline Sağlık Sigortası & 0.5 & 0.5 & 0.7 & 0.7 & 0.7 & 0.8 & 0.8 & 0.8 & 0.8 & 0.8 & 0.8 & 0.8 \\
\hline
\end{tabular}

Kaynak: Insurance Europe, European Insurance Industry Database, 2017.

Ek Tablo 5: Sigorta Sektörü Toplam Yatırım Portföyünün GSYiH'ye Oranı (\%)

\begin{tabular}{|l|c|c|c|c|c|c|c|c|c|c|c|c|}
\hline & 2004 & 2005 & 2006 & 2007 & 2008 & 2009 & 2010 & 2011 & 2012 & 2013 & 2014 & 2015 \\
\hline Avrupa Birliği & 49.30 & 52.90 & 53.50 & 53.10 & 48.20 & 54.30 & 55.40 & 53.80 & 57.60 & 58.30 & 61.50 & 60.60 \\
\hline Tüm Avrupa & 49.70 & 53.40 & 54.00 & 53.70 & 48.80 & 55.00 & 56.10 & 54.50 & 58.40 & 59.10 & 62.30 & 61.50 \\
\hline
\end{tabular}

Kaynak: Insurance Europe, European Insurance Industry Database, 2017. 